\title{
PENGALAMAN KERJA, PRESTASI KERJA, DAN LOYALITAS KARYAWAN BERPENGARUH TERHADAP PROMOSI JABATAN PADA PRIME PLAZA HOTEL
}

\author{
I Gusti Agung Putu Ari Dharma Jaya 1 \\ I Gusti Ayu Dewi Adnyani ${ }^{2}$ \\ ${ }^{1,2}$ Fakultas Ekonomi dan Bisnis Universitas Udayana (Unud), Bali, Indonesia \\ email: aridharma97@gmail.com
}

\begin{abstract}
ABSTRAK
Promosi jabatan merupakan suatu perpindahan di dalam suatu organisasi dari satu posisi ke posisi lainnya yang melibatkan peningkatan upah maupun maupun status. Penelitian ini bertujuan untuk menganalisis pengaruh pengalaman kerja, prestasi kerja, dan loyalitas karyawan terhadap promosi jabatan. Penelitian dilakukan di Prime Plaza Hotel Sanur, dengan Simple Random Sampling, sebanyak 79 responden. Pengumpulan data melalui wawancara dan penyebaran kuesioner. Teknik analisis data yang digunakan adalah analisis regresi linier berganda. Hasil penelitian menunjukkan bahwa pengalaman kerja berpengaruh positif dan signifikan terhadap promosi jabatan, prestasi kerja berpengaruh positif dan signifikan terhadap promosi jabatan, dan loyalitas karyawan berpengaruh positif dan signifikan terhadap promosi jabatan. Upaya meningkatkan promosi jabatan pada karyawan, pemimpin hendaknya mampu memberikan keadilan didalam memberikan promosi jabatan sehingga karyawan merasa bangga, nyaman, dan setia terhadap perusahaannya serta mampu membuat karyawan tersebut meningkatkan kinerjanya dan memperoleh pengalaman yang lebih banyak.
\end{abstract}

Kata kunci : Loyalitas Karyawan, Pengalaman Kerja, Prestasi Kerja, Promosi Jabatan

\begin{abstract}
Job promotion is a move within an organization from one position to another which involves an increase in wages or status. This study aims to analyze the effect of work experience, work performance, and employee loyalty to promotion. The study was conducted at Prime Plaza Hotel Sanur, using Simple Random Sampling, with 79 respondents. Data collected by interviews and questionnaires. The data analysis technique used is multiple linear regression analysis. The results showed that work experience had positive and significant effect on job promotions, work performance had a positive and significant effect on job promotions, and employee loyalty had a positive and significant effect on job promotions. Efforts to improve the promotion of positions to employees, leaders should be able to provide justice in providing promotions so that employees feel proud, comfortable, and loyal to the company and be able to make employees improve their performance and gain more experience.

Keywords: Employee Loyalty, Work Experience, Job Performance, Job Promotion
\end{abstract}




\section{PENDAHULUAN}

Perkembangan bisnis yang begitu pesat saat ini, mengharuskan perusahaan untuk memperhatikan faktor - faktor produksi yang ada. Salah satu faktor produksi dalam perusahaan adalah sumber daya manusia (SDM) selain sumber daya alam dan sumber daya modal. SDM adalah harta atau aset paling berharga yang dimiliki oleh satu organisasi atau perusahaan, karena keberhasilan organisasi sangat ditentukan oleh unsur manusia. Perkembangan bisnis yang begitu pesat saat ini, mengharuskan perusahaan untuk memperhatikan faktor-faktor produksi yang ada. Kemajuan teknologi, perkembangan informasi, tersedianya modal, tanpa SDM sulit bagi perusahaan untuk mencapai tujuannya. Organisasi diharuskan mengatur posisi yang tepat bagi tenaga kerjanya dengan sistem promosi untuk menghasilkan kontribusi karyawan yang maksimal. Karyawan yang menginginkan promosi jabatan diharuskan untuk bersungguh - sungguh dalam bekerja, karena promosi jabatan ini didasari oleh berbagai faktor seperti pengalaman kerja, prestasi kerja dan loyalitas karyawan, serta dengan promosi jabatan maka tugas dan tanggung jawab karyawan akan lebih besar. (Fuanida, 2016)

Promosi jabatan merupakan salah satu hal yang penting dalam sebuah organisasi dimana promosi berkaitan dengan kenaikan jabatan serta peningkatan tanggung jawab yang lebih besar dari jabatan yang sebelumnya. Berdasarkan beberapa penelitian yang dilakukan oleh Mandiangan \& Rahyuda (2015) menyatakan bahwa promosi jabatan dipengaruhi oleh prestasi kerja. Selain itu penelitian yang dilakukan oleh Mandiangan \& Rahyuda (2015), Andhara dkk. (2015) menyatakan bahwa promosi jabatan juga dipengaruhi oleh loyalitas karyawan. Selain prestasi kerja dan loyalitas karyawan, dalam penelitian ini juga menguji pengaruh pengalaman kerja terhadap promosi jabatan.

Penelitian ini tentang promosi jabatan yang terjadi pada Prime Plaza Hotel, yang terletak di Jalan Hang Tuah 46 Sanur 80228 Bali, Indonesia. Prime Plaza Hotel merupakan resort bintang empat yang memiliki lokasi strategis, hanya beberapa menit dari pusat perbelanjaan dan pantai yang bagus, serta atraksi budaya dan alam Bali. Hotel ini sudah berdiri selama 23 tahun. Fasilitas utama yang dimiliki Prime Plaza Hotel yaitu 329 kamar tamu bebas rokok, 2 restoran dan 2 bar/lounge, kolam renang outdoor, klub kesehatan, layanan spa, teras, dan lapangan tenis outdoor. Jumlah karyawan Prime Plaza Hotel Sanur, Bali pada tahun 2019 sebanyak 370 orang, dari jumlah tersebut tentunya akan ada permasalahan yang dijumpai. Salah satu permasalahan yang terjadi ada pada karyawan hotel tersebut, yaitu adanya keinginan karyawan terhadap promosi jabatan mereka agar selalu lancar. Menurut ketentuan hotel, seorang karyawan yang ingin di promosikan jabatannya harus memiliki pengalaman kerja yang cukup, kinerja yang baik serta bagaimana loyalitas karyawan terhadap perusahaan.

Hasil dari observasi yang dilakukan adalah masih banyak ditemukan karyawan yang pengalamannya belum memadai. Kondisi ini dapat dilihat dari beberapa karyawan yang masih sangat bergantung dengan atasan, padahal dengan memiliki pengalaman kerja akan membantu karyawan mengerjakan pekerjaannya tanpa perlu menunggu perintah. Minimnya pengalaman kerja yang dimiliki tidak terlepas dari masa kerja mereka. 
Tabel 1.

Masa Kerja Karyawan Prime Plaza Hotel Sanur-Bali Tahun 2019

\begin{tabular}{|c|c|c|}
\hline No & Masa Kerja (Tahun) & Jumlah Karyawan (Orang) \\
\hline 1 & $\leq 5$ & 190 \\
\hline 2 & $6-10$ & 80 \\
\hline 3 & $11-15$ & 35 \\
\hline 4 & $16-20$ & 40 \\
\hline \multirow[t]{2}{*}{5} & $21-25$ & 25 \\
\hline & Total & 370 \\
\hline
\end{tabular}

Sumber : Prime Plaza Hotel Sanur-Bali, 2019

Berdasarkan hasil wawancara dengan 5 orang karyawan, yaitu pada bagian Front Office dan HRD, fenomena yang terdapat pada Prime Plaza Hotel Sanur, Bali bahwa promosi jabatan tidak berasaskan keadilan, dimana karyawan yang sangat dekat dengan atasan lebih diprioritaskan dalam promosi jabatan daripada karyawan yang tidak terlalu dekat dengan atasan. Pentingnya promosi jabatan bagi karyawan akan optimal apabila tidak hanya dilihat berdasarkan kedekatan dengan atasan saja akan tetapi dapat juga dilihat dari pengalaman kerja, prestasi kerja, dan bagaimana loyalitas karyawan terhadap perusahaan sehingga tercapainya keadilan didalam perusahaan memberikan suatu promosi jabatan.

Pengalaman kerja berkaitan dengan promosi jabatan karena dengan memiliki banyak pengalaman kerja akan membantu seseorang dalam menyelesaikan tugas - tugasnya tanpa perlu menunggu perintah, selain itu pengalaman kerja juga mempermudah karyawan mengerjakan tugas-tugas yang diberikan karena sudah memiliki kemampuan yang didapat dari pengalaman-pengalaman bekerja sebelumnya. Pengalaman kerja dapat dilihat dari total waktu karyawan dalam bekerja di perusahaan yang sebelumnya maupun perusahaan yang sekarang. Human resources departement tentu akan memperhatikan pengalaman kerja seseorang dalam memberikan suatu jabatan, sehingga jabatan dalam suatu perusahaan dirasa memang sudah tepat bila diduduki oleh karyawan tersebut (Campbell, 2015).

Kot-Radojewska \& Timenko (2018) menyatakan pengalaman dan kinerja memiliki keterikatan terhadap promosi jabatan lewat pengetahuan dan keterampilan. Mendapatkan pengalaman selama masa studi memungkinkan seseorang meningkatkan pemahaman mereka tentang tempat kerja. On the job training adalah salah satu cara bagaimana perusahaan memberikan pengalaman bagi karyawannya. Le Tran \& Chiou-shu (2015) menyatakan jika nilai yang diperoleh dari pengalaman kerja semakin besar maka semakin meningkat kinerja yang dimiliki karyawan yang berpengaruh terhadap promosi jabatan yang akan diterima. Selain itu promosi jabatan di beberapa perusahaan secara umum dilakukan berdasarkan prestasi kerja karyawan, dimana karyawan yang memiliki prestasi kerja yang tinggi akan diprioritaskan dalam promosi jabatan.

Sebelum memberikan keputusan promosi, atasan hendaknya melakukan penilaian prestasi kerja seobyektif mungkin dan menjujung tinggi keadilan dalam memberikan penilaian. Ketidakjelasan sistem promosi jabatan dapat 
menyebabkan timbulnya ketidakpuasan kerja karyawan (Koopmans et al., 2014). Setiap karyawan yang ada dalam perusahaan tentu memiliki prestasi kerja yang berbeda. Kinerja karyawan akan optimal jika organisasi mampu menciptakan kondisi yang dapat mengakibatkan karyawan disiplin dalam bekerja dan memungkinkan karyawan untuk mengembangkan dan meningkatkan kemampuan serta keterampilan yang dimiliki secara optimal (Sumarauw dkk., 2014). Anyim et al. (2014) dalam penelitiannya menemukan fakta bahwa penilaian dalam prestasi kerja digunakan untuk menentukan kemungkinan karyawan dipromosikan ke jabatan yang lebih tinggi.

Pihak HRD menyatakan bahwa untuk menilai prestasi kerja karyawan dilakukan berdasarkan observasi langsung dengan cara melihat bagaimana kinerja karyawannya apakah sudah sesuai dengan standar atau tidak. Prestasi kerja merupakan hasil kerja secara kualitas dan kuantitas yang dicapai oleh seseorang pegawai dalam melaksanakan tugasnya sesuai dengan tanggung jawab yang diberikan kepadanya. Prestasi kerja yang baik menunjukkan sumber daya yang kompeten, dan memiliki loyalitas kerja yang tinggi terhadap perusahaan. Prestasi kerja karyawan yang menunjukkan peningkatan dapat membantu karyawan tersebut untuk di promosikan jabatannya, karena salah satu syarat promosi jabatan adalah prestasi kerja yang dapat dilihat dari catatan-catatan kinerja karyawan yang ada (Mandiangan \& Rahyuda, 2015).

Loyalitas karyawan juga mempengaruhi promosi jabatan dimana loyalitas karyawan merupakan kepatuhan karyawan untuk bekerja di perusahaan tempat seseorang mencari nafkah. Loyalitas kerja merupakan suatu sikap mental karyawan yang ditunjukkan kepada keberadaan perusahaan, sehingga karyawan akan tetap bertahan dalam perusahaan, tanpa mempedulikan kondisi perusahaan saat itu. Kita dapat mengatakan bahwa seorang karyawan setia kepada organisasinya ketika dia menunjukkan komitmen dan keyakinan bahwa bekerja di organisasi adalah pilihan terbaik baginya. Waqas et al. (2014) berpendapat bahwa karyawan yang loyal adalah orang yang memiliki komitmen tinggi dalam mengembangkan organisasi tempat ia bekerja.

Loyalitas kerja merupakan salah satu faktor yang mempengaruhi promosi jabatan, karena karyawan yang memiliki loyalitas kerja tinggi dianggap mampu memberikan hasil yang maksimal dalam pencapaian tujuan perusahaan (Onsardi, 2017). Loyalitas kerja merupakan kesetiaan karyawan terhadap perusahaan yang akan menimbulkan rasa tanggung jawab, sehingga karyawan akan tetap bertahan dalam perusahaan tersebut walaupun perusahaan dalam keadaan maju atau mundur (Stephani \& Wibawa, 2014). Antoncic \& Antoncic (2014) menyatakan bahwa loyalitas kerja karyawan pada perusahaan diukur dari kepercayaan karyawan pada tujuan perusahaan, menerima tujuan sebagai karya mereka sendiri untuk kesejahteraan bersama, untuk tetap mengabdi di perusahaan. Karyawan yang merasakan adanya kesenangan yang mendalam terhadap pekerjaan yang dilakukan akan melaksanakan pekerjannya dengan baik dan hal tersebut mutlak diperlukan demi kesuksesan organisasi itu sendiri (Putra, 2019). 
Sikap loyal diperlukan agar karyawan tersebut dapat bekerja tidak hanya untuk dirinya sendiri tetapi juga untuk kepentingan perusahaan. Sikap loyalitas kerja ini berasal dari kesadaran yang tinggi bahwa antara karyawan dengan perusahaan merupakan dua pihak yang saling membutuhkan (Anyim et al., 2014). Karyawan mesti diperlakukan secara layak dan adil, sehingga mereka dapat betah dalam melaksanakan tugas, disamping bersungguh-sungguh dan penuh tanggung jawab serta berdisiplin. Loyalitas kerja seseorang harus memiliki keinginan yang tinggi, kemampuan atau skill individu, serta lingkungan kerja yang baik untuk mengerjakan pekerjaannya (Brown et al., 2015).

Jumlah karyawan di Prime Plaza Hotel tentu tidak semua memiliki kesempatan yang sama untuk memperoleh promosi jabatan, karena keterbatasan jabatan yang ada atau tersedia. Faktor-faktor yang akan mempengaruhi promosi jabatan adalah pengalaman kerja yang dapat dilihat dari masa kerjanya, kemampuan menyelesaikan pekerjaan tanpa menunggu perintah, dan prestasi kerja dapat dilihat dari bagaimana disiplin kerjanya, kecakapan, kejujuran dalam bekerja, serta loyalitas karyawan yang dapat dilihat dari bagaimana hubungan kerjasama di dalam pekerjaan. Jika semua kriteria penilaian di dalam promosi jabatan sudah terpenuhi, tetapi kesempatan guna mengisi jabatan yang sedang kosong belum ada, maka promosi jabatan belum bisa dilaksanakan. Kriteria penilaian promosi jabatan di Prime Plaza Hotel yakni dilihat dari kerjasama, kecakapan, kedisiplinan, tanggung jawab, sikap kerja, hasil kerja, dan kreatifitas.

HRD menyatakan bahwa promosi jabatan bagi karyawan tidak terstruktur. Karyawan yang akan di promosikan jabatannya bisa saja mendapatkan jabatan yang menyimpang jauh dari jabatan sebelumnya. Hal ini disesuaikan dengan kedudukan jabatan yang sedang kosong dan sebelum menduduki posisi tersebut karyawan akan diberi pendidikan lanjutan dan pelatihan selama beberapa bulan. Dari pernyataan tersebut terdapat permasalahan mengenai promosi jabatan yang tidak sesuai dengan pengalaman yang dimiliki karyawan tersebut. Jumlah karyawan yang sudah mendapatkan kesempatan promosi jabatan dari tahun 2014 sampai 2018 di Prime Plaza Hotel Sanur, Bali, dapat dilihat pada Tabel 2.

Tabel 2.

Tingkat Promosi Jabatan Karyawan Prime Plaza Hotel Sanur-Bali

\begin{tabular}{|c|c|c|c|c|c|}
\hline Tahun & Masa Kerja (Tahun) & $\begin{array}{l}\text { Jumlah } \\
\text { (Orang) }\end{array}$ & Promosi & $\begin{array}{l}\text { Jumlah } \\
\text { (Orang) }\end{array}$ & Karyawan \\
\hline 2014 & 379 & 15 & & 25 & \\
\hline 2015 & 374 & 13 & & 29 & \\
\hline 2016 & 369 & 11 & & 34 & \\
\hline 2017 & 372 & 13 & & 29 & \\
\hline 2018 & 370 & 10 & & 37 & \\
\hline Total & & & & 370 & \\
\hline
\end{tabular}

Sumber : Prime Plaza Hotel Sanur-Bali, 2019 
Berdasarkan Tabel 2. menunjukkan bahwa jumlah karyawan Prime Plaza Hotel dan jumlah promosi jabatan dari tahun ke tahun berfluktuasi. Pelaksanaan beberapa tahapan sistem promosi jabatan masih banyak terjadi permasalahan. Permasalahan pertama terletak pada proses evaluasi, apabila penilaian hanya dilihat dari satu kriteria penilaian saja untuk mempromosikan karyawan, belum tentu karyawaan tersebut benar - benar unggul pada kriteria lainnya. Hal ini dipicu karena sistem promosi jabatan yang dibuat hanya tertulis dan terstruktur dengan baik di atas kertas saja tetapi kenyataannya berbanding terbalik di lapangan. Permasalahan kedua, yakni adanya faktor kedekatan yang lebih diperhitungankan dibandingkan prestasi kerja dalam penentuan promosi jabatan karyawan. Ini berarti hasil kerja yang baik dari kualitas tidak digunakan sebagai dasar dalam promosi jabatan.

Penelitian ini menggunakan Teori Kebutuhan Untuk Berprestasi (Achievement Theory). David McCleland (2009) dalam teorinya mengemukakan bahwa individu mempunyai cadangan energi potensial. Energi ini dilepaskan dan dikembangkan tergantung pada kekuatan atau dorongan motivasi individu dan situasi serta peluang yang tersedia. Teori ini memfokuskan pada tiga kebutuhan akan prestasi (Achiefment), kebutuhan kekuasaan (Power), dan kebutuhan afiliasi. Dalam penelitian ini pengalaman dan prestasi seseorang di dalam bekerja ditentukan oleh aktivitas kegiatan belajar serta pelatihan yang dilaksanakan dengan mengutamakan loyalitas kerja pada perusahaan sehingga mendapatkan penghargaan atau reward berupa promosi jabatan (Azmi \& Heryanto, 2019).

Pada dasarnya seseorang yang memiliki pengalaman kerja lebih banyak tentu akan lebih mengerti apa yang harus dilakukan ketika menghadapi sebuah masalah yang muncul. Selain itu karyawan tersebut akan lebih cepat dalam bekerja dan tidak harus beradaptasi dengan tugas yang dijalankan karena diyakini sudah memiliki pengalaman. Pengalaman akan membentuk pengetahuan dan ketrampilan serta sikap yang lebih menyatu pada diri seseorang, jika bidang pekerjaan yang ditangani selama masih bekerja merupakan bidang yang sejenis yang pada akhirnya akan membentuk spesialisasi pengalaman kerja diperoleh selama seseorang bekerja pada suatu perusahaan dari mulai masuk hingga saat ini (Wang et al., 2014).

Umumnya proses promosi jabatan dilakukan dengan mempertimbangkan kompetensi individu, pengalaman individu, dan kebutuhan organisasi ( $\mathrm{Yu}$ et al., 2015). Penelitian Ali et al. (2014) menyatakan bahwa pengalaman kerja merupakan salah satu kriteria penting dalam meningkatkan laba masa depan. Medhiantari (2016) menunjukan dalam penelitian yang telah dilakukan bahwa pengalaman kerja berpengaruh positif dan signifikan terhadap promosi jabatan. Cindy (2018) juga memperkuat penelitian dengan penelitian yang telah dilakukan yang menyatakan bahwa pengalaman kerja berpengaruh signifikan terhadap promosi jabatan.

Putri (2018) mempertegas dalam penelitian yang telah dilakukan bahwa pengalaman kerja berpengaruh positif terhadap promosi jabatan dengan koefisien regresi sebesar 0,256 yang berarti semakin baik pengalaman kerja akan berdampak pada semakin baik pula promosi jabatan yang akan diterima. Dalam pernyataan tersebut mengandung makna bahwa pengalaman 
kerja berkaitan dengan ukuran lama waktu atau masa kerja yang telah ditempuh seseorang untuk dapat memahami tugas-tugas suatu pekerjaan. Dengan demikian dapat disusun suatu hipotesis yang menjelaskan hubungan antara pengalaman kerja dengan promosi jabatan, sebagai berikut :

$\mathrm{H}_{1} \quad$ : Pengalaman Kerja berpengaruh positif terhadap Promosi Jabatan

Prestasi kerja karyawan sangat berpengaruh dalam membantu pihak manajemen dalam mengambil keputusan mengenai kenaikan jabatan, pemindahan pada unit yang sama maupun pemutusan hubungan kerja pada perusahaan dan berperan penting dalam perusahaan guna untuk meningkatkan produktivitas kerja. Prestasi kerja karyawan sangat menentukan promosi jabatan karena apabila penilaian tidak dilakukan dengan baik, maka perusahaan akan salah dalam menempatkan karyawan pada jabatan yang diberikan.

Penelitian Macdonald \& Sulsky (2014) menyatakan bahwa penilaian prestasi kerja dapat menentukan promosi jabatan seorang karyawan. Fernandes et al. (2015) menyatakan bahwa prestasi kerja memiliki pengaruh yang signifikan pada promosi jabatan. Sasmita \& Mujiati (2016) juga memperkuat penelitian dengan penelitian yang telah dilakukan yang menyatakan bahwa prestasi kerja berpengaruh positif dan signifikan terhadap promosi jabatan. Sungkono \& Dewi (2017) mempertegas dalam penelitian yang telah dilakukan bahwa prestasi kerja berpengaruh positif terhadap promosi jabatan dengan koefisien regresi sebesar 0,588. Untuk mendapatkan promosi jabatan yang maksimal, maka karyawan harus memiliki kinerja yang sesuai dengan jabatan yang akan dipromosikan. Dalam pernyataan tersebut mengandung makna bahwa semakin baik prestasi kerja atau kinerja karyawan, maka semakin besar peluang karyawan tersebut untuk di promosikan jabatannya. Dengan demikian dapat disusun suatu hipotesis yang menjelaskan hubungan antara prestasi kerja dengan promosi jabatan, sebagai berikut :

$\mathrm{H}_{2} \quad$ : Prestasi Kerja berpengaruh positif terhadap Promosi Jabatan

Pencapaian tujuan perusahaan dapat didukung dengan hasil kerja yang baik oleh karyawan dan hasil kerja yang baik dapat disebabkan oleh loyalitas karyawan. Oleh karena itu loyalitas menjadi salah satu syarat dilakukannya promosi jabatan. Loyalitas karyawan diidentifikasi dengan loyalitas khusus kepada perusahaan, yang dimanifestasikan dalam kesediaan untuk dikaitkan dengannya lebih lama, tidak hanya di saat-saat yang baik, tetapi juga dalam keadaan yang tidak menguntungkan (Murali et al., 2017). Artinya seorang karyawan dapat dikatakan memiliki loyalitas pada perusahaan apabila karyawaan tersebut tetap bertahan pada perusahaan dengan kondisi yang bagaimanapun.

Loyalitas karyawan mempengaruhi promosi jabatan karena menyangkut rasa tanggung jawab, pengorbanan, dan perasaan memiliki perusahaan (Onsardi, 2017).. Penelitian Soegandhi dkk. (2014) mendapatkan hasil bahwa loyalitas karyawan berpengaruh positif terhadap promosi jabatan, dimana loyalitas kerja merupakan salah satu faktor timbulnya promosi jabatan. Pratimi dan Utama (2016) menunjukan dalam penelitian yang telah dilakukan bahwa loyalitas berpengaruh positif dan signifikan terhadap promosi jabatan. 
Sungkono \& Dewi (2017) mempertegas dalam penelitian yang telah dilakukan bahwa loyalitas kerja berpengaruh positif terhadap promosi jabatan dengan koefisien regresi sebesar 0,268. Artinya loyalitas kerja mempunyai pengaruh dalam penentuan proses promosi jabatan yang ada di perusahaan. Dalam pernyataan tersebut mengandung makna bahwa loyalitas kerja berpengaruh terhadap promosi jabatan karena menyangkut rasa tanggung jawab, pengorbanan, dan perasaan memiliki perusahaan sehingga akan meningkatkan kinerja dan diharapkan memberikan yang terbaik bagi perusahaan. Dengan demikian dapat disusun suatu hipotesis yang menjelaskan hubungan antara loyalitas karyawan dengan promosi jabatan, sebagai berikut :

$\mathrm{H}_{3} \quad$ : Loyalitas Karyawan berpengaruh positif terhadap Promosi Jabatan

\section{METODE PENELITIAN}

Penelitian ini menggunakan desain kuantitatif kausal. Hal ini berarti penelitian berfokus pada pengaruh pengalaman kerja, prestasi kerja dan loyalitas karyawan sebagai variabel independen terhadap promosi jabatan sebagai variabel dependen. Lokasi penelitian ini berada di Sanur, tepatnya di Jalan Hang Tuah 46 Sanur, Bali 80228. Alasan memilih lokasi penelitian tersebut karena Prime Plaza Hotel Sanur, Bali memiliki masalah mengenai promosi jabatan, dimana promosi jabatan tidak berasaskan keadilan. Karyawan yang sangat dekat dengan atasan lebih diprioritaskan dalam promosi jabatan daripada karyawan yang tidak terlalu dekat dengan atasan. Sehingga lokasi ini sangat baik jika dilakukan penelitian ilmiah. Obyek dari penelitian ini yaitu Pengalaman Kerja, Prestasi Kerja, Loyalitas Karyawan, dan Promosi Jabatan. Variabel bebas dalam penelitian ini adalah Pengalaman Kerja $\left(\mathrm{X}_{1}\right)$, Prestasi Kerja $\left(\mathrm{X}_{2}\right)$, dan Loyalitas Karyawan $\left(\mathrm{X}_{3}\right)$. Variabel terikat dalam penelitian ini adalah Promosi Jabatan (Y).

Pengalaman kerja adalah masa kerja seorang karyawan untuk dapat memahami tugas-tugasnya. Variabel pengalaman kerja dapat diukur dengan indikator-indikator sebagai berikut : Kelancaran pekerjaan, Peningkatan prestasi kerja, Penyelesaian tugas tanpa menunggu perintah, Tanggung jawab Prestasi kerja atau kinerja merupakan hasil capaian yang dimiliki oleh seorang karyawan yang digunakan untuk melihat baik buruknya suatu pekerjaan. Variabel prestasi kerja dapat diukur dengan indikator-indikator : Kinerja tugas (Task performance), Kinerja kontekstual (Contextual performance).

Loyalitas karyawan merupakaan suatu sikap kesetiaan karyawan yang dilihat tidak disaat kondisi perusahan sedang naik saja, melainkan disaat kondisi perusahaan sedang turun juga bahwa karyawan tersebut tetap bertahan. Variabel loyalitas dapat diukur dengan indikator-indikator sebagai berikut :Kepatuhan, Tanggung jawab, Pengabdian, Kejujuran. Promosi jabatan (job promotion) merupakan suatu perpindahan didalam organisasi yang meliputi peningkatan jabatan, upah, status, tanggung jawab dari jabatan yang sebelumnya. Variabel promosi jabatan dapat diukur dengan indikator-indikator sebagai berikut : Kerja sama, Kecakapan, Kepemimpinan, Komunikatif, 
Populasi dalam penelitian ini adalah karyawan pada Prime Plaza Hotel Sanur, Bali tahun 2019 sebanyak 370 karyawan. jumlah sampel yang digunakan dalam penelitian ini adalah sebanyak 79 karyawan pada Prime Plaza Hotel Sanur, Bali. Metode penentuan sampel untuk menentukan sampel yang akan digunakan dalam penelitian ini menggunakan teknik Probability Sampling dengan Simple Random Sampling. Data kualitatif dalam penelitian ini adalah gambaran umum mengenai Prime Plaza Hotel Sanur, Bali. Data kuantitatif dalam penelitian ini adalah skor jawaban responden dan jumlah karyawan Prime Plaza Hotel Sanur, Bali. Sumber Primer merupakan data yang berkaitan dengan responden.Sumber Sekunder adalah data tentang perusahaan yang diperoleh dari web resmi perusahaan tersebut. Data yang dikumpulkan dalam penelitian ini menggunakan metode-metode wawancara dan kuesioner.

\section{HASIL DAN PEMBAHASAN}

Tabel 3.

Karakteristik Responden Berdasarkan Usia

\begin{tabular}{cccc}
\hline No & Klasifikasi & Jumlah & Presentase (\%) \\
\hline 1 & $21-25$ Tahun & 19 & 24,1 \\
2 & $26-30$ Tahun & 47 & 59,5 \\
3 & $>30$ Tahun & 13 & 16,5 \\
& Jumlah & $\mathbf{7 9}$ & $\mathbf{1 0 0}$ \\
\hline
\end{tabular}

Sumber: Data Primer Diolah, 2019

Responden dengan usia 26 - 30 Tahun paling mendominasi diantara yang lainnya yakni 47 responden atau 59,5\%. Sedangkan usia yang jumlahnya paling rendah yakni responden dengan usia $>30$ Tahun yakni 13 responden atau 16,5\%. Hal ini berarti bahwa karyawan Prime Plaza Hotel Sanur, Bali rata-rata berumur 26-30 yang merupakan usia produktif dan kreatif dalam bekerja.

Responden dengan jenis kelamin pria yakni 44 orang atau $55,7 \%$ lebih mendominasi dibandingkan dengan responden dengan jenis kelamin wanita yakni 35 orang atau 44,3\%. Hal ini berarti bahwa Prime Plaza Hotel Sanur, Bali lebih memerlukan banyak tenaga laki-laki seperti Security, Engineering, Kitchen, Housekeeping.

Tabel 4.

Karakteristik Responden Berdasarkan Jenis Kelamin

\begin{tabular}{cccc}
\hline No & Klasifikasi & Jumlah & Presentase (\%) \\
\hline 1 & Pria & 44 & 55,7 \\
2 & Wanita & 35 & 44,3 \\
\hline & Jumlah & $\mathbf{7 9}$ & $\mathbf{1 0 0}$ \\
\hline
\end{tabular}

Sumber: Data Primer Diolah, 2019

Responden dengan pendidikan terakhir SMA pada Tabel 5. paling mendominasi yakni 51 orang atau $64,6 \%$. Sedangkan responden yang paling sedikit yakni responden dengan pendidikan terakhir sarjana yakni 13 responden atau 
16,5\%. Hal ini berarti bahwa lulusan SMA/SMK merupakan lulusan yang telah memiliki keterampilan dan langsung menjurus ke dunia perhotelan.

Tabel 5.

Karakteristik Responden Berdasarkan Pendidikan Terakhir

\begin{tabular}{cccc}
\hline No & Klasifikasi & Jumlah & Presentase (\%) \\
\hline 1 & SMA/SMK & 51 & 64,6 \\
2 & Diploma (D3) & 15 & 19,0 \\
3 & Sarjana (S1) & 13 & 16,5 \\
& Jumlah & $\mathbf{7 9}$ & $\mathbf{1 0 0}$ \\
\hline
\end{tabular}

Sumber: Data Primer Diolah, 2019

Tabel 6.

Karakteristik Responden Berdasarkan Lama Bekerja

\begin{tabular}{cccc}
\hline No & Klasifikasi & Jumlah & Presentase (\%) \\
\hline 1 & $1-5$ Tahun & 33 & 41,8 \\
2 & 6-10 Tahun & 31 & 39,2 \\
3 & $>10$ Tahun & 15 & 19,0 \\
& Jumlah & $\mathbf{7 9}$ & $\mathbf{1 0 0}$ \\
\hline
\end{tabular}

Sumber: Data Primer Diolah, 2019

Responden dengan lama bekerja $1-5$ tahun yang paling mendominasi yakni 33 responden atau $41,8 \%$. Dibandingkan dengan responden dengan lama bekerja $>10$ tahun yang paling sedikit yakni 15 responden atau 19,0\%. Ini menyatakan bahwa karyawan pada Prime Plaza Hotel Sanur cukup berpengalaman apabila dilihat dari masa kerja.

Tabel 7.

Rekapitulasi Hasil Uji Reliabilitas Instrumen Penelitian

\begin{tabular}{clcl}
\hline No. & \multicolumn{1}{c}{ Variabel } & $\begin{array}{c}\text { Cronbadh's } \\
\text { Alpha }\end{array}$ & Keterangan \\
\hline 1 & Pengalaman Kerja $\left(\mathrm{X}_{1}\right)$ & 0,865 & Reliabel \\
2 & Prestasi Kerja $\left(\mathrm{X}_{2}\right)$ & 0,881 & Reliabel \\
3 & Loyalitas Karyawan $\left(\mathrm{X}_{3}\right)$ & 0,852 & Reliabel \\
4 & Promosi Jabatan $(\mathrm{Y})$ & 0,913 & Reliabel \\
\hline
\end{tabular}

Sumber: Data Primer Diolah, 2019

Seluruh instrumen penelitian yang digunakan untuk mengukur variabel Pengalaman Kerja, Prestasi Kerja, Loyalitas Kerja, dan Promosi Jabatan memiliki nilai koefisien korelasi dengan skor total seluruh item pernyataan lebih besar dari 0,30. Hal ini menunjukkan bahwa butir-butir pernyataan dalam instrument penelitian tersebut valid dan layak digunakan sebagai instrument penelitian. Hasil uji reliabilitas menunjukkan bahwa seluruh instrumen penelitian memiliki koefisien Cronbach's Alpha lebih dari 0,70. Jadi dapat dinyatakan bahwa seluruh variabel telah memenuhi syarat reliabilitas atau kehandalan sehingga dapat digunakan untuk melakukan penelitian. 
Tabel 8.

Rekapitulasi Hasil Uji Validitas Instrumen Penelitian

\begin{tabular}{|c|c|c|c|c|}
\hline Variabel & Indikator & R hitung & R table & Keterangan \\
\hline & $\mathrm{X}_{1.1}$ & 0,827 & 0,30 & Valid \\
\hline Pengalaman & $\mathrm{X}_{1.2}$ & 0,877 & 0,30 & Valid \\
\hline \multirow[t]{5}{*}{$\operatorname{Kerja}\left(X_{1}\right)$} & $\mathrm{X}_{1.3}$ & 0,775 & 0,30 & Valid \\
\hline & $\mathrm{X}_{1.4}$ & 0,917 & 0,30 & Valid \\
\hline & $\mathrm{X}_{2.1}$ & 0,790 & 0,30 & Valid \\
\hline & $\mathrm{X}_{2.2}$ & 0,639 & 0,30 & Valid \\
\hline & $\mathrm{X}_{2.3}$ & 0,642 & 0,30 & Valid \\
\hline \multirow{8}{*}{$\begin{array}{l}\text { Prestasi Kerja } \\
\qquad\left(\mathrm{X}_{2}\right)\end{array}$} & $\mathrm{X}_{2.4}$ & 0,814 & 0,30 & Valid \\
\hline & $\mathrm{X}_{2.5}$ & 0,838 & 0,30 & Valid \\
\hline & $\mathrm{X}_{2.6}$ & 0,657 & 0,30 & Valid \\
\hline & $\mathrm{X}_{2.7}$ & 0,783 & 0,30 & Valid \\
\hline & $\mathrm{X}_{2.8}$ & 0,782 & 0,30 & Valid \\
\hline & $\mathrm{X}_{3.1}$ & 0,640 & 0,30 & Valid \\
\hline & $\mathrm{X}_{3.2}$ & 0,707 & 0,30 & Valid \\
\hline & $\mathrm{X}_{3.3}$ & 0,694 & 0,30 & Valid \\
\hline \multirow{9}{*}{$\begin{array}{c}\text { Loyalitas } \\
\text { Karyawan }\left(\mathrm{X}_{3}\right)\end{array}$} & $\mathrm{X}_{3.4}$ & 0,694 & 0,30 & Valid \\
\hline & $\mathrm{X}_{3.5}$ & 0,737 & 0,30 & Valid \\
\hline & $X_{3.6}$ & 0,826 & 0,30 & Valid \\
\hline & $X_{3.7}$ & 0,736 & 0,30 & Valid \\
\hline & $\mathrm{X}_{3.8}$ & 0,640 & 0,30 & Valid \\
\hline & $\mathrm{Y}_{.1}$ & 0,662 & 0,30 & Valid \\
\hline & $\mathrm{Y}_{.2}$ & 0,760 & 0,30 & Valid \\
\hline & $\mathrm{Y}_{.3}$ & 0,797 & 0,30 & Valid \\
\hline & $Y_{.4}$ & 0,629 & 0,30 & Valid \\
\hline \multirow{7}{*}{$\begin{array}{c}\text { Promosi } \\
\text { Jabatan(Y) }\end{array}$} & $Y_{.5}$ & 0,668 & 0,30 & Valid \\
\hline & $Y_{.6}$ & 0,828 & 0,30 & Valid \\
\hline & $\mathrm{Y}_{.7}$ & 0,785 & 0,30 & Valid \\
\hline & $Y_{.8}$ & 0,864 & 0,30 & Valid \\
\hline & $\mathrm{Y}_{.9}$ & 0,829 & 0,30 & Valid \\
\hline & $Y_{.10}$ & 0,694 & 0,30 & Valid \\
\hline & $Y_{.11}$ & 0,607 & 0,30 & Valid \\
\hline
\end{tabular}

Sumber: Data Primer Diolah, 2019

Pengalaman kerja secara keseluruhan baik hal ini dapat dilihat dari keseluruhan rata-rata nilai pengalaman kerja yaitu 3,83. Nilai rata-rata tertinggi pada pernyataan "Saya bertanggung jawab atas tugas yang dibebankan". Nilai rata-rata terendah terdapat pada pernyataan "Pengalaman kerja membuat saya mampu menyelesaikan tugas-tugas tanpa menunggu perintah atasan". Prestasi kerja secara keseluruhan baik hal ini dapat dilihat dari keseluruhan rata-rata nilai prestasi kerja yaitu 3,87. Nilai rata-rata tertinggi pada pernyataan "Saya menargetkan hasil yang harus dicapai dalam pekerjaan". Nilai rata-rata terendah terdapat pada pernyataan "Saya memiliki solusi kreatif untuk menghadapi masalah baru". Loyalitas karyawan secara keseluruhan baik hal ini dapat dilihat dari keseluruhan rata-rata nilai loyalitas karyawan yaitu 3,95. Nilai rata-rata tertinggi pada pernyataan "Saya selalu berusaha memberikan sumbangan tenaga dalam menyelesaikan permasalahan pada 
perusahaan". Nilai rata-rata terendah terdapat pada pernyataan "Saya berupaya bekerja sesuai job description yang ditetapkan oleh organisasi atau pimpinan". Promosi jabatan secara keseluruhan baik hal ini dapat dilihat dari keseluruhan ratarata nilai promosi jabatan yaitu 4,17. Nilai rata-rata tertinggi pada pernyataan "Karyawan dapat bekerjasama dengan baik secara vertikal merupakan alasan promosi jabatan". Nilai rata-rata terendah terdapat pada pernyataan "Karyawan yang kreatif dalam bekerja dapat dipertimbangkan untuk promosi jabatan".

Tabel 9.

Hasil Uji Normalitas

\begin{tabular}{|c|c|c|}
\hline \multirow[b]{2}{*}{$\mathbf{N}$} & & Unstandardized Residual \\
\hline & & ( \\
\hline \multirow[t]{2}{*}{ Normal Parameters $^{\mathrm{a}, \mathrm{b}}$} & Mean & .0000000 \\
\hline & Std. Deviation & 2.53311507 \\
\hline \multirow[t]{3}{*}{ Most Extreme Differences } & Absolute & .085 \\
\hline & Positive & .058 \\
\hline & Negative & -.085 \\
\hline Test Statistic & & .085 \\
\hline Asymp. Sig. (2-tailed) & & $.200^{\mathrm{c}, \mathrm{d}}$ \\
\hline
\end{tabular}

Tabel 10.

Hasil Uji Heteroskedastisitas

\begin{tabular}{lccccc}
\hline & \multicolumn{2}{c}{$\begin{array}{c}\text { Unstandardized } \\
\text { Coefficients }\end{array}$} & $\begin{array}{c}\text { Standardized } \\
\text { Coefficients }\end{array}$ & & \\
\cline { 2 - 4 } Model & B & $\begin{array}{c}\text { Std. } \\
\text { Error }\end{array}$ & Beta & T & Sig. \\
\hline 1 (Constant) & 5.167 & 1.394 & & 3.707 & .000 \\
$\quad$ Pengalaman Kerja & -.127 & .067 & -.225 & -1.907 & .060 \\
$\quad$ Prestasi Kerja & .071 & .051 & .215 & 1.393 & .168 \\
$\quad$ Loyalitas Karyawan & -.105 & .056 & -.289 & -1.876 & .065 \\
\hline
\end{tabular}

Sumber: Data Primer Diolah, 2019

Nilai signifikansi dengan menggunakan uji Asymp. Sig. (2-tailed) sebesar $0,200>0,05$ maka dapat disimpulkan nahwa model regresi yang digunakan dalam penelitian ini terdistribusi secara normal. Nilai signifikan untuk variabel pengalaman kerja sebesar $0,060(0,060>0,05)$, nilai signifikan untuk variabel prestasi kerja sebesar 0,168 $(0,168>0,05)$, dan nilai signifikan untuk variabel loyalitas karyawan sebesar $0,065(0,065>0,05)$. Semua variabel bebas memiliki nilai signifikansi $>0,05$, maka tidak terjadi heteroskedastisitas pada model regresi.

Nilai tolerance untuk variabel pengalaman kerja sebesar $0,854(0,854>$ $0,1)$ dengan nilai VIF sebesar $1,171(1,171<10)$, nilai tolerance untuk variabel prestasi kerja sebesar 0,502 $(0,502>0,1)$ dengan nilai VIF sebesar $1,990(1,990<10)$, dan nilai tolerance untuk variabel loyalitas karyawan sebesar 0,504 $(0,504>0,1)$ dengan nilai VIF sebesar $1,984(1,984<10)$. Semua variabel pada model regresi berganda tersebut memiliki nilai tolerance lebih besar dari 0,1 dan nilai VIF lebih kecil dari 10 maka dapat disimpulkan bahwa model regresi yang digunakan bebas multikolinieritas. 
Tabel 11.

Hasil Uji Multikolinieritas

\begin{tabular}{llcc}
\hline & & \multicolumn{2}{c}{ Collinearity Statistics } \\
\cline { 3 - 4 } Model & & Tolerance & VIF \\
\hline 1 & Pengalaman Kerja & .854 & 1.171 \\
& Prestasi Kerja & .502 & 1.990 \\
& Loyalitas Karyawan & .504 & 1.984 \\
\hline
\end{tabular}

Sumber: Data Primer Diolah, 2019

Teknik analisis ini digunakan untuk mengetahui seberapa besar pengaruh variabel bebas yaitu: Pengalaman Kerja $\left(\mathrm{X}_{1}\right)$, Prestasi Kerja $\left(\mathrm{X}_{2}\right)$, Loyalitas Karyawan $\left(\mathrm{X}_{3}\right)$, terhadap variabel terikatnya yaitu Promosi Jabatan (Y).

Tabel 12.

Hasil Analisis Regresi Linier Berganda

\begin{tabular}{|c|c|c|c|c|c|c|}
\hline & \multirow{3}{*}{ Model } & \multicolumn{2}{|c|}{$\begin{array}{l}\text { Unstandardized } \\
\text { Coefficients }\end{array}$} & \multirow{3}{*}{$\begin{array}{c}\begin{array}{c}\text { Standardized } \\
\text { Coefficients }\end{array} \\
\text { Beta } \\
\end{array}$} & \multirow{3}{*}{$\mathbf{T}$} & \multirow{3}{*}{ Sig. } \\
\hline & & & Std. & & & \\
\hline & & B & Error & & & \\
\hline \multirow[t]{4}{*}{1} & (Constant) & 14.812 & 2.660 & & 5.570 & .000 \\
\hline & Pengalaman Kerja & .314 & .127 & .179 & 2.469 & 016 \\
\hline & Prestasi Kerja & .494 & .097 & .482 & 5.110 & .000 \\
\hline & Loyalitas Karyawan & .348 & 107 & .307 & 3.263 & .002 \\
\hline $\mathrm{R}$ & & 0,815 & & & & \\
\hline \multicolumn{2}{|c|}{ R Square } & 0,664 & & & & \\
\hline \multicolumn{2}{|c|}{ Adjusted $R$ Square } & 0,651 & & & & \\
\hline \multirow{2}{*}{\multicolumn{2}{|c|}{ F hitung }} & 49,499 & & & & \\
\hline & Sig. & 0,000 & & & & \\
\hline
\end{tabular}

Berdasarkan Tabel 12. dapat dibuat persamaan regresi linier berganda berikut: $\mathrm{Y}=14,812+0,314 \mathrm{X}_{1}+0,494 \mathrm{X}_{2}+0,348 \mathrm{X}_{3}$

Konstanta $(\alpha)$ sebesar 14,812 memiliki arti apabila Pengalaman Kerja, Prestasi Kerja, dan Loyalitas Karyawan memiliki nilai konstan pada angka nol maka nilai Promosi Jabatan akan bernilai sebesar 14,812. Koefisien regresi variabel Pengalaman Kerja sebesar 0,314 bernilai positif memiliki arti apabila Pengalaman Kerja bernilai 1 satuan maka Promosi Jabatan juga akan semakin meningkat sebesar 0,314 dengan asumsi variabel lainnya konstan pada angka nol. Koefisien regresi variabel Prestasi Kerja sebesar 0,494 bernilai positif memiliki arti apabila Prestasi Kerja bernilai 1 satuan maka Promosi Jabatan akan meningkat sebesar 0,494 dengan asumsi variabel lainnya konstan pada angka nol. Koefisien regresi variabel Loyalitas Karyawan sebesar 0,348 bernilai positif memiliki arti apabila Loyalitas Karyawan bernilai 1 satuan maka Promosi Jabatan akan meningkat sebesar 0,348 dengan asumsi variabel lainnya konstan pada angka nol. 
Tabel 13.

Hasil Uji F-test

\begin{tabular}{llccccc}
\hline Model & & $\begin{array}{c}\text { Sum of } \\
\text { Squares }\end{array}$ & df & $\begin{array}{c}\text { Mean } \\
\text { Square }\end{array}$ & F & Sig. \\
\hline 1 & Regression & 990.968 & 3 & 330.323 & 49.499 & $.000^{\text {b }}$ \\
& Residual & 500.500 & 75 & 6.673 & & \\
& Total & 1491.468 & 78 & & & \\
\hline
\end{tabular}

Sumber: Data Primer Diolah, 2019

Hasil uji signifikansi simultan (Uji $\mathrm{F}$ ) diperoleh nilai signifikansi $\mathrm{F}$ sebesar 0,000. Nilai signifikan $0,000<0,05$ mempunyai arti bahwa Pengalaman Kerja, Prestasi Kerja, dan Loyalitas Karyawan diduga secara signifikan berhubungan dengan Promosi Jabatan.

Tabel 14.

Hasil Uji t-test

\begin{tabular}{llccccc}
\hline & & $\begin{array}{c}\text { Unstandardized } \\
\text { Coefficients }\end{array}$ & $\begin{array}{c}\text { Standardized } \\
\text { Coefficients }\end{array}$ & & \\
\cline { 3 - 5 } Model & & Std. & & Beta & t & Sig. \\
\hline 1 & (Constant) & 14.812 & 2.660 & & 5.570 & .000 \\
& Pengalaman Kerja & .314 & .127 & .179 & 2.469 & .016 \\
& Prestasi Kerja & .494 & .097 & .482 & 5.110 & .000 \\
& Loyalitas Karyawan & .348 & .107 & .307 & 3.263 & .002 \\
\hline
\end{tabular}

Sumber: Data Primer Diolah, 2019

Hasil uji t pengaruh Pengalaman Kerja terhadap Promosi Jabatan diperoleh nilai signifikansi sebesar 0,016 dengan nilai koefisien regresi sebesar 0,314 bernilai positif. Nilai signifikansi $0,016<0,05$ mengindikasikan bahwa $\mathrm{H}_{1}$ diterima. Hasil ini mempunyai arti bahwa Pengalaman Kerja diduga secara signifikan berhubungan dengan Promosi Jabatan. Hasil uji t pengaruh Prestasi Kerja terhadap Promosi Jabatan diperoleh nilai signifikansi sebesar 0,000 dengan nilai koefisien regresi sebesar 0,494 bernilai positif. Nilai signifikansi $0,000<0,05$ mengindikasikan bahwa $\mathrm{H}_{2}$ diterima. Hasil ini mempunyai arti bahwa Prestasi Kerja diduga secara signifikan berhubungan dengan Promosi Jabatan. Hasil uji $t$ pengaruh Loyalitas Karyawan terhadap Promosi Jabatan diperoleh nilai signifikansi sebesar 0,002 dengan nilai koefisien regresi sebesar 0,348 bernilai positif. Nilai signifikansi $0,002<0,05$ mengindikasikan bahwa $\mathrm{H}_{3}$ diterima. Hasil ini mempunyai arti bahwa Loyalitas Karyawan diduga secara signifikan berhubungan dengan Promosi Jabatan.

Nilai adjusted $\mathrm{R}^{2}$ sebesar 0,651 berarti $65,1 \%$ perubahan (naik turun) pada Promosi Jabatan yang dipengaruhi oleh Pengalaman Kerja, Prestasi Kerja, dan Loyalitas Karyawan, sementara sisanya sejumlah 34,9\% dipengaruhi oleh faktor - faktor lain diluar penelitian ini. 
Tabel 15.

Hasil Analisis Koefisien Determinasi

\begin{tabular}{lcccc}
\hline Model & R & R Square & $\begin{array}{c}\text { Adjusted R } \\
\text { Square }\end{array}$ & Std. Error of the Estimate \\
\hline 1 & $.815^{\text {a }}$ & .664 & .651 & 2.583 \\
\hline
\end{tabular}

Sumber: Data Primer Diolah, 2019

Berdasarkan hasil uji t pengaruh Pengalaman Kerja terhadap Promosi Jabatan diperoleh nilai signifikansi sebesar 0,016 dengan nilai koefisien regresi sebesar 0,314 bernilai positif. Nilai signifikansi $0,016<0,05$ mengindikasikan bahwa $\mathrm{H}_{1}$ diterima. Hasil ini mempunyai arti bahwa Pengalaman Kerja diduga secara signifikan berhubungan dengan Promosi Jabatan. Hal ini berarti jika Pengalaman Kerja semakin baik, maka Promosi Jabatan semakin baik, sebaliknya jika Pengalaman Kerja semakin buruk maka Promosi Jabatan akan semakin buruk pula.

Pada dasarnya seseorang yang memiliki pengalaman kerja lebih banyak tentu akan lebih mengerti apa yang harus dilakukan ketika menghadapi sebuah masalah yang muncul. Selain itu karyawan tersebut akan lebih cepat dalam bekerja dan tidak harus beradaptasi dengan tugas yang dijalankan karena diyakini sudah memiliki pengalaman. Pengalaman akan membentuk pengetahuan dan ketrampilan serta sikap yang lebih menyatu pada diri seseorang, jika bidang pekerjaan yang ditangani selama masih bekerja merupakan bidang yang sejenis yang pada akhirnya akan membentuk spesialisasi pengalaman kerja diperoleh selama seseorang bekerja pada suatu perusahaan dari mulai masuk hingga saat ini.

Penelitian Ali et al. (2014) menyatakan bahwa pengalaman kerja merupakan salah satu kriteria penting dalam meningkatkan laba masa depan. Medhiantari (2016) menunjukan dalam penelitian yang telah dilakukan bahwa pengalaman kerja berpengaruh positif dan signifikan terhadap promosi jabatan. Cindy (2018) juga memperkuat penelitian dengan penelitian yang telah dilakukan yang menyatakan bahwa pengalaman kerja berpengaruh signifikan terhadap promosi jabatan. Putri (2018) mempertegas dalam penelitian yang telah dilakukan bahwa pengalaman kerja berpengaruh positif terhadap promosi jabatan dengan koefisien regresi sebesar 0,256 yang berarti semakin baik pengalaman kerja akan berdampak pada semakin baik pula promosi jabatan yang akan diterima. Dalam pernyataan tersebut mengandung makna bahwa pengalaman kerja berkaitan dengan ukuran lama waktu atau masa kerja yang telah ditempuh seseorang untuk dapat memahami tugas-tugas suatu pekerjaan.

Berdasarkan hasil uji $t$ pengaruh Prestasi Kerja terhadap Promosi Jabatan diperoleh nilai signifikansi sebesar 0,000 dengan nilai koefisien regresi sebesar 0,494 bernilai positif. Nilai signifikansi $0,000<0,05$ mengindikasikan bahwa $\mathrm{H}_{2}$ diterima. Hasil ini mempunyai arti bahwa Prestasi Kerja diduga secara signifikan berhubungan dengan Promosi Jabatan. Hal ini berarti jika Prestasi Kerja semakin baik, maka Promosi Jabatan semakin baik, sebaliknya jika Prestasi Kerja semakin buruk maka Promosi Jabatan akan semakin buruk pula. Prestasi kerja karyawan sangat berpengaruh dalam 
membantu pihak manajemen dalam mengambil keputusan mengenai kenaikan jabatan, pemindahan pada unit yang sama maupun pemutusan hubungan kerja pada perusahaan dan berperan penting dalam perusahaan guna untuk meningkatkan produktivitas kerja. Prestasi kerja karyawan sangat menentukan promosi jabatan karena apabila penilaian tidak dilakukan dengan baik, maka perusahaan akan salah dalam menempatkan karyawan pada jabatan yang diberikan

Penelitian Macdonald \& Sulsky (2014) menyatakan bahwa penilaian prestasi kerja dapat menentukan promosi jabatan seorang karyawan. Fernandes et al. (2015) menyatakan bahwa prestasi kerja memiliki pengaruh yang signifikan pada promosi jabatan. Sasmita \& Mujiati (2016) juga memperkuat penelitian dengan penelitian yang telah dilakukan yang menyatakan bahwa prestasi kerja berpengaruh positif dan signifikan terhadap promosi jabatan. Awadh \& Saad (2014) mempertegas dalam penelitian yang telah dilakukan bahwa prestasi kerja berpengaruh positif terhadap promosi jabatan dengan koefisien regresi sebesar 0,588. Untuk mendapatkan promosi jabatan yang maksimal, maka karyawan harus memiliki kinerja yang sesuai dengan jabatan yang akan dipromosikan. Dalam pernyataan tersebut mengandung makna bahwa semakin baik prestasi kerja atau kinerja karyawan, maka semakin besar peluang karyawan tersebut untuk di promosikan jabatannya.

Berdasarkan hasil uji t pengaruh Loyalitas Karyawan terhadap Promosi Jabatan diperoleh nilai signifikansi sebesar 0,002 dengan nilai koefisien regresi sebesar 0,348 bernilai positif. Nilai signifikansi $0,002<0,05$ mengindikasikan bahwa $\mathrm{H}_{3}$ diterima. Hasil ini mempunyai arti bahwa Loyalitas Karyawan diduga secara signifikan berhubungan dengan Promosi Jabatan. Hal ini berarti jika Loyalitas Karyawan semakin baik, maka Promosi Jabatan semakin baik, sebaliknya jika Loyalitas Karyawan semakin buruk maka Promosi Jabatan akan semakin buruk pula. Pencapaian tujuan perusahaan dapat didukung dengan hasil kerja yang baik oleh karyawan dan hasil kerja yang baik dapat disebabkan oleh loyalitas karyawan. Oleh karena itu loyalitas menjadi salah satu syarat dilakukannya promosi jabatan. Loyalitas karyawan diidentifikasi dengan loyalitas khusus kepada perusahaan, yang dimanifestasikan dalam kesediaan untuk dikaitkan dengannya lebih lama, tidak hanya di saat-saat yang baik, tetapi juga dalam keadaan yang tidak menguntungkan (Murali et al., 2017). Artinya seorang karyawan dapat dikatakan memiliki loyalitas pada perusahaan apabila karyawaan tersebut tetap bertahan pada perusahaan dengan kondisi yang bagaimanapun

Loyalitas karyawan mempengaruhi promosi jabatan karena menyangkut rasa tanggung jawab, pengorbanan, dan perasaan memiliki perusahaan (Onsardi, 2017).. Penelitian Soegandhi dkk. (2014) mendapatkan hasil bahwa loyalitas karyawan berpengaruh positif terhadap promosi jabatan, dimana loyalitas kerja merupakan salah satu faktor timbulnya promosi jabatan. Pratimi dan Utama (2016) menunjukan dalam penelitian yang telah dilakukan bahwa loyalitas berpengaruh positif dan signifikan terhadap promosi jabatan. Azmi \& Heryanto (2019) juga memperkuat penelitian dengan penelitian yang telah dilakukan yang menyatakan bahwa Komitmen karyawan dan loyalitas berpengaruh signifikan pada promosi jabatan. Sungkono \& Dewi (2017) mempertegas dalam penelitian yang 
telah dilakukan bahwa loyalitas kerja berpengaruh positif terhadap promosi jabatan dengan koefisien regresi sebesar 0,268. Artinya loyalitas kerja mempunyai pengaruh dalam penentuan proses promosi jabatan yang ada di perusahaan. Dalam pernyataan tersebut mengandung makna bahwa loyalitas kerja berpengaruh terhadap promosi jabatan karena menyangkut rasa tanggung jawab, pengorbanan, dan perasaan memiliki perusahaan sehingga akan meningkatkan kinerja dan diharapkan memberikan yang terbaik bagi perusahaan.

Berdasarkan hasil penelitian dan pemaparan diperoleh bahwa pengalaman kerja berpengaruh positif terhadap promosi jabatan. Hasil tersebut mengimplikasikan bahwa promosi jabatan dimaksimalkan dengan cara meningkatkan kuantitas dan kualitas pengalaman kerja. Pengalaman kerja dapat ditingkatkan melalui menyelesaikan dan melaksanakan beragam tugas dan tanggung jawab. Sedangkan prestasi kerja berpengaruh positif terhadap promosi jabatan. Hasil tersebut berimplikasi bahwa promosi jabatan dapat diperoleh jika prestasi yang dimiliki karyawan juga optimal. Prestasi dapat diperoleh dengan cara menyelesaikan berbagai tanggung jawab sesuai tugas, pokok, dan fungsi yang dimiliki.Selain itu, Loyalitas Karyawan berpengaruh positif terhadap Promosi Jabatan. Hal tersebut berimplikasi bahwa untuk memperoleh promosi jabatan dapat diperoleh dengan menunjukan loyalitas yang optimal.

Berdasarkan hasil analisis data dan pemaparan di atas terdapat beberapa keterbatasan yaitu faktor - faktor yang mempengaruhi promosi jabatan hanya dikontruksi dari tiga variabel yaitu pengalaman kerja, prestasi kerja, dan loyalitas kerja sedangkan masih terdapat faktor lain yang berpeluang memiliki andil dalam mempengaruhi promosi jabatan. Selain itu sampel yang digunakan masih terbatas dari aspek lokasi sehingga masih bisa dikembangkan.

\section{SIMPULAN}

Berdasarkan hasil analisis penelitian dan hasil pembahasan maka simpulan dari penelitian ini adalah Pengalaman Kerja berpengaruh positif terhadap Promosi Jabatan. Hal ini berarti jika Pengalaman Kerja semakin baik, maka Promosi Jabatan semakin baik, sebaliknya jika Pengalaman Kerja semakin buruk maka Promosi Jabatan akan semakin buruk pula. Prestasi Kerja berpengaruh positif terhadap Promosi Jabatan. Hal ini berarti jika Prestasi Kerja semakin baik, maka Promosi Jabatan semakin baik, sebaliknya jika Prestasi Kerja semakin buruk maka Promosi Jabatan akan semakin buruk pula. Loyalitas Karyawan berpengaruh positif terhadap Promosi Jabatan. Hal ini berarti jika Loyalitas Karyawan semakin baik, maka Promosi Jabatan semakin baik, sebaliknya jika Loyalitas Karyawan semakin buruk maka Promosi Jabatan akan semakin buruk pula.

Berdasarkan hasil analisis penelitian dan hasil pembahasan maka saran dari penelitian ini adalah Indikator yang memiliki rata-rata terendah dari variabel pengalaman kerja adalah saya mampu menyelesaikan tugas - tugas tanpa menunggu perintah atasan. Dari indikator tersebut atasan harus selalu mengkoordinir bawahannya agar bawahannya tahu kemana arah mereka 
bekerja, karena karyawan tidak bisa menyelesaikan pekerjaannya tanpa adanya perintah dari atasan. Indikator yang memiliki rata-rata terendah dari variabel prestasi kerja adalah saya memiliki solusi kreatif untuk mengadapi masalah baru. Dari indikator tersebut atasan harus selalu memberikan dorongan, motivasi ataupun masukan kepada seluruh karyawannya agar karyawan memiliki solusi ketika menghadapi masalah baru, karena tidak semua karyawan memiliki solusi kreatif untuk menghadapi masalah baru.

Indikator yang memiliki rata-rata terendah dari variabel loyalitas karyawan adalah saya berupaya bekerja sesuai job description yang ditetapkan oleh organisasi atau pimpinan. Dari indikator tersebut atasan harus meningkatkan pengawasan dan memperhatikan karyawannya pada saat bekerja apakah sudah sesuai dengan job description yang telah diberikan atau tidak, karena bisa saja karyawan tersebut merasa job description yang telah ditetapkan itu tidak sesuai dengan keinginan karyawan sehingga karyawan bekerja tidak mengikuti perintah. Indikator yang memiliki rata-rata terendah dari variabel promosi jabatan adalah karyawan yang kreatif dalam bekerja dapat dipertimbangkan untuk promosi jabatan. Dari indikator tersebut atasan harus memberikan sedikit kebebasan pada karyawannya agar karyawan tidak terlalu baku terhadap peraturan yang ada sehingga karyawan merasa nyaman dan kreatif dalam bekerja.

\section{REFERENSI}

Ali, S. M., Shaharudin, M. R., \& Anuar, A. (2014). The Association Between Job Positions, Work Experience and Career Satisfaction: The Case of Malaysian's Academic Staff. Asian Social Science, 8(10), 35-44. https://doi.org/10.5539/ass.v8n10p35

Andhara, S. De, Utami, H. N., \& Mayowan, Y. (2015). Pengaruh Senioritas Dan Loyalitas Terhadap Promosi Jabatan ( Studi pada Karyawan Departemen Kebijakan Ekonomi dan Moneter Bank Indonesia Jakarta ) Abstrak. Jurnal Administrasi Bisnis (JAB), 22(1), 1-9.

Antoncic, J. A., \& Antoncic, B. (2014). Employee Loyalty and Its Impact on Firm Growth. International Journal of Management \& Information Systems, 15(1), 81-87. https://doi.org/10.2991/meici-17.2017.143

Anyim, F. C., Ikemefuna, C. O., \& Shadare, A. O. (2014). Internal Versus External Staffing in Nigeria: Cost-Benefit Implications. Journal of Management and Strategy, 2(4), 35-42. https://doi.org/10.5430/jms.v2n4p35

Awadh, A. M., \& Saad, A. M. (2014). Impact of Organizational Culture on Employee Performance. International Review of Management and Business Research, 2(1), 168-175.

Azmi, \& Heryanto. (2019). Effect of Organizational Culture and Leadership on Employee Performance at the Regional Office the Ministry of Religion of 
West Sumatra Province with Work Motivation as an Intervening Variable. Archives of Business Research, 7(1), 348-371.

Brown, S., McHardy, J., McNabb, R., \& Taylor, K. (2015). Workplace Performance, Worker Commitment, and Loyalty. IZA Discussion. https://doi.org/10.1111/j.1530-9134.2011.00306.x

Campbell, K. (2015). Flexible Work Schedules, Virtual Work Programs, and Employee Productivity. Walden, 1(1), 1-20.

Cindy M. Arnold, Kojo, C., \& Greis M. Sendow. (2018). Pengaruh Evaluasi Kinerja Dan Pengalaman Kerja Terhadap Promosi Jabatan Pada Badan Pertanahan Nasional Kota Manado. Jurnal EMBA, 6(4), 3028-3037.

Fernandes, M. D. T., Pithadia, D. V., \& Rajkot (2015). A Study On The Effectiveness Of Performance Appraisal System At Suzlon. International Journal Of Management Research And Review, 2(6), 1001-1013.

Fuanida, A. (2016). Pengaruh Kompensasi, Stres Kerja, Dan Motivasi Terhadap Loyalitas Kerja Karyawan CV. Sapu Dunia Semarang. Jurnal Ilmu Administrasi Bisnis, 4(6), 128-211.

Koopmans, L., Bernaards, C. M., Hildebrandt, V. H., Vet, H. C. W. D., \& Beek, A. V. D. (2014). Construct Validity of the Individual work performance questionnarie. Journal Of Occupational Dan Environmental Medicine, 56(3), 331-337.

Kot-Radojewska, M., \& Timenko, I. V. (2018). Employee loyalty to the organization in the context of the form of employment. Oeconomia Copernicana, 9(3), 511-527.

Le Tran, T. T., \& Chiou-shu, J. H. (2015). Factors Affecting Employee Performance-Evidence From Petrovietnam Engineering Consultancy J.S.C. Human Resource Management Journal, 4(2), 1-13.

Macdonald, H. A., \& Sulsky, L. M. (2014). Rating Formats and Rater Training Redux: A Context-Specific Approach For Enhancing The Effectiveness of Performance Management. Canadian Journal of Behavioural Science, 41(4), 227-240. https://doi.org/10.1037/a0015165

Mandiangan, E., \& Rahyuda, A. (2015). Pengaruh Prestasi Kerja, Senioritas, Dan Loyalitas Terhadap Promosi Jabatan Pada Discovery Kartika Plaza Hotel Bali. E-Jurnal Manajemen Unud, 4(5), 1386-1405.

Medhiantari, I. A. N., \& Yuniari, M. (2016). Pengaruh Prestasi Kerja Dan Pengalaman Kerja Terhadap Promosi Jabatan Pada PT. Bank Rakyat Indonesia (Persero) Tbk. Cabang Gajah Mada Denpasar. E-Jurnal Manajemen Unud, 3(7), 2035-2049.

Murali, S., Poddar, A., \& Seema, A. (2017). Employee Loyalty , Organizational Performance \& Performance Evaluation - A Critical Survey. IOSR Journal 
of Business and Management Ver . III, 19(8), 2319-7668. https://doi.org/10.9790/487X-1908036274

Onsardi. (2017). The Effect Of Compensation, Empowerment, And Job Satisfaction On Employee Loyalty. International Journal Of Scientific Research And Management, 5(12), 7590-7599.

Pratimi, D. M., \& Utama, I. W. M. (2016). Pengaruh Loyalitas dan Prestasi Kerja Terhadap Promosi Jabatan Pada The Jayakarta Bali Hotel. E-Jurnal Manajemen Unud, 5(11), 7446-7472.

Putra, I. W. S. (2019). Pengaruh Lingkungan Kerja, Stres Kerja Dan Kompensasi Terhadap Loyalitas Karyawan. E-Jurnal Manajemen Unud, 8(2), 7746-7774.

Putri, F. I. (2018). Pengaruh Prestasi Kerja , Disiplin, Komitmen , Dan Pengalaman Kerja Terhadap Promosi Jabatan ( Studi Pada PTPN X Kebun Kertosari ). Jurnal Fakultas Ekonomi Universitas Muhammadiyah Jember, 4(2), 1-18.

Sasmita, I. A. G. D., \& Mujiati, N. W. (2016). Pengaruh Prestasi Kerja dan Kompetensi Karyawan terhadap Promosi Jabatan Pada Inna Sindhu Beach Hotel Sanur, Denpasar. E-Jurnal Manajemen Unud, 5(8), 4807-4834.

Soegandhi., V. M., Setiawan, E. M. S., \& Roy. (2013). Pengaruh Kepuasan Kerja dan Loyalitas Kerja terhadap Organizational Citizenship Behavior pada karyawan PT. Surya Timur Sakti Jatim. AGORA, 1(1), 1-10.

Stephani, L. A., \& Wibawa, I. M. A. (2014). Pengaruh Kompensasi dan Lingkungan Kerja pada Loyalitas Karyawan Berdasarkan Jenis Kelamin. E-Jurnal Manajemen Unud, 3(10), 3078-3095.

Sumarauw, B., Saerang, D. P. E., \& Pandowo, M. (2014). Analysis The Influence of Organizational Culture: Power Distance, Individualism and Masculinity to Employee Performance at PT. Freeport Indonesia. Jurnal EMBA, 2(2), 15501558.

Sungkono, S. W., \& Dewi, I. M. (2017). Pengaruh Prestasi Kerja, Loyalitas Kerja terhadap Promosi Jabatan Di PT. Bali Pawiwahan Coco Group. E-Jurnal Manajemen Unud, 6(4), 1991-2017.

Wang, Y.-F., Chiang, M.-H., \& Lee, Y.-J. (2014). The relationships amongst the intern anxiety, internship outcomes, and career commitment of hospitality college students. Journal of Hospitality, Leisure, Sport and Tourism Education, 15(4), 86-93.

Waqas, A., Bashir, U., Sattar, M. F., Abdullah, H. M., Hussain, I., Anjum, W., ... Arshad, R. (2014). Factors Influencing Job Satisfaction and Its Impact on Job Loyalty. International Journal of Learning and Development, 4(2), 141-161. https://doi.org/10.5296/ijld.v4i2.6095 
I Gusti Agung Putu Ari Dharma Jaya, Pengalaman Kerja, Prestasi...

Yu, C., Sun, H., \& Han, B. (2015). Design and Implementation of Chinese High Star-Level Hotel Management Information System. Education Technology, Management and Humanities Science, 1(7), 234-237. 